\title{
Receptor guanylyl cyclase-G is a novel thermosensor in Grueneberg ganglion neurons involved in coolness-induced ultrasonic distress calls in mice
}

\author{
Ying-Chi Chao', Heinz Breer², Yuh-Charn Lin", Chih-Cheng Chen ${ }^{1}$, Joerg Fleischer ${ }^{2}$, Ruey-Bing Yang ${ }^{1,3^{*}}$ \\ From 6th International Conference on cGMP: Generators, Effectors and Therapeutic Implications \\ Erfurt, Germany. 28-30 June 2013
}

\section{Background}

In mammals, detection of ambient temperatures is mainly mediated by thermosensory neurons residing in the dorsal root ganglion (DRG) and trigeminal ganglion (TG) [1-3]. Recently, neurons in the Grueneberg ganglion (GG) of the murine nasal vestibule have been found to be activated by cool temperatures $[4,5]$. Unlike coolness-sensitive cells in the DRG and TG, neurons in the GG lack the TRPM8 channel [6] which is considered as a principal detector of cold [1-3]. Therefore, GG neurons are supposedly endowed with a so far unknown thermosensor. Interestingly, coolness-sensitive GG neurons express signaling elements associated with cyclic guanosine monophosphate (cGMP), including the cGMP-activated ion channel CNGA3 and receptor guanylyl cyclase-G (GC-G) [6-8]. Recent observations suggest that cGMP signaling is crucial for thermotransduction in the GG [8]. However, whether $\mathrm{GC}-\mathrm{G}$ directly acts as a temperature sensor remains elusive.

\section{Materials and methods}

A combination of biochemical and molecular biology methods, $\mathrm{Ca}^{2+}$ imaging as well as behavioural studies comparing wild-type and GC-G-knockout mice was used to elucidate the molecular and biological function of GC-G in sensing cool temperatures.

\section{Results}

We show that GC-G is a thermosensory receptor that can be maximally stimulated by cool temperatures of about

\footnotetext{
* Correspondence: rbyang@ibms.sinica.edu.tw

${ }^{1}$ Institute of Biomedical Sciences, Academia Sinica, Taipei, Taiwan

Full list of author information is available at the end of the article
}

$15^{\circ} \mathrm{C}$ in both in vivo cellular cGMP accumulation assays and in vitro GC assays with a purified recombinant protein. Cells co-expressing GC-G and CNGA3 respond to cool temperatures via a rapid influx of calcium. Furthermore, we found a marked coolness-induced expression of the activity-dependent gene c-Fos in GG neurons of wild-type neonatal pups but not in GC-G-knockout conspecifics. Consistent with these findings, coolness-elicited ultrasonic vocalizations were significantly impaired in GC-G-knockout compared to wild-type pups.

\section{Conclusion}

Our data suggest that GC-G is a novel thermosensory protein and that GG activation via GC-G by coolness is critical for the generation of ultrasound calls by isolated pups to elicit maternal care.

\section{Authors' details \\ ${ }^{1}$ Institute of Biomedical Sciences, Academia Sinica, Taipei, Taiwan. ${ }^{2}$ Institute of Physiology, University of Hohenheim, Stuttgart, Germany. ${ }^{3}$ Institute of Pharmacology, School of Medicine, National Yang-Ming University, Taipei, Taiwan.}

\section{Published: 29 August 2013}

\section{References}

1. Bautista DM, Siemens J, Glazer JM, Tsuruda PR, Basbaum Al, Stucky CL, Jordt SE, Julius D: The menthol receptor TRPM8 is the principal detector of environmental cold. Nature 2007, 448:204-208.

2. Colburn RW, Lubin ML, Stone DJ Jr, Wang Y, Lawrence D, D'Andrea MR, Brandt M, Liu Y, Flores CM, Qin N: Attenuated cold sensitivity in TRPM8 null mice. Neuron 2007, 54:379-386.

3. Dhaka A, Murray AN, Mathur J, Earley TJ, Petrus MJ, Patapoutian A: TRPM8 is required for cold sensation in mice. Neuron 2007, 54:371-378.

4. Mamasuew K, Breer H, Fleischer J: Grueneberg ganglion neurons respond to cool ambient temperatures. Eur J Neurosci 2008, 28:1775-1785. 
5. Schmid A, Pyrski M, Biel M, Leinders-Zufal T, Zufall F: Grueneberg ganglion neurons are finely tuned cold sensors. J Neurosci 2010, 30:7563-7568.

6. Fleischer J, Mamasuew K, Breer H: Expression of cGMP signaling elements in the Grueneberg ganglion. Histochem Cell Biol 2009, 131:75-88.

7. Liu CY, Frase $S E$, Koos DS: Grueneberg ganglion olfactory subsystem employs a cGMP signaling pathway. J Comp Neurol 2009, 516:36-48.

8. Mamasuew K, Michalakis S, Breer H, Biel M, Fleischer J: The cyclic nucleotide-gated ion channel CNGA3 contributes to coolness-induced responses of Grueneberg ganglion neurons. Cell Mol Life Sci 2010, 67:1859-1869.

doi:10.1186/2050-6511-14-S1-P14

Cite this article as: Chao et al: Receptor guanylyl cyclase-G is a novel thermosensor in Grueneberg ganglion neurons involved in coolnessinduced ultrasonic distress calls in mice. BMC Pharmacology and Toxicology 2013 14(Suppl 1):P14.

\section{Submit your next manuscript to BioMed Central} and take full advantage of:

- Convenient online submission

- Thorough peer review

- No space constraints or color figure charges

- Immediate publication on acceptance

- Inclusion in PubMed, CAS, Scopus and Google Scholar

- Research which is freely available for redistribution

Submit your manuscript at www.biomedcentral.com/submit
C Biomed Central 